\title{
Analysis of Influence of Intellectual Capital and Capital Adequacy Ratio on Bank Performance in Indonesia
}

\author{
Sri Indrastuti, Hamdi Agustin*, Amries Rusli Tanjung \\ Faculty of Economics \\ University Islam of Riau \\ Riau, Indonesia \\ *hamdiagustin@yahoo.com
}

\begin{abstract}
The purporse of this research to analyze the influence of intellectual capital and capital adequacy ratio on financial performance in banking companies listed on the Indonesian Stock Exchange (ISX). The sample of this research is determined by purposive sampling method based on the criteria of banking industry listed in ISX and publish the financial report and present the data completely including data from the variables studied during the research period (2013-2017), so that the obtained sample of 20 banks. This research uses multiple linear regression models. The results of this study concluded that Value Added Human Capital (VAHU), Structural Capital Value Added (STVA), Value Added Intellectual Capital (VAIC) and Capital Adequacy Ratio (CAR) have influence to bank performance.
\end{abstract}

Keywords: financial performance, intellectual capital, return on asset, banking

\section{INTRODUCTION}

The interesting thing about the use of intellectual capital as a tool to determine the value of a company is the book value of a company's [1]. This study was conducted to determine the components of intellectual capital, and which components of intellectual capital are considered to have value by companies, services and investment. And how intellectual capital is described by firms in traditional financial statements and examines the role of intellectual capital as value creation and makes corporate competitive advantage.

Intellectual Capital where the way employees think and act is influenced by the effectiveness of knowledge owned by managers in setting policies and systems that apply in the company. Intellectual Capital is defined as the value-added knowledge of an organization where the success of the organization depends on creating, discovering, capturing, and instilling that knowledge. This issue arises when a shift from a production-based economy to a knowledge-based economy and service, as well as the idea of an invisible balance sheet, where intellectual capital is more valuable than fixed assets.

The relationship between value added intellectual coefficient (VAIC) and financial using regression analysis [2]. According to Saengchan [3] study examined the role of intellectual capital in creating value in the banking industry in
Thailand. The purpose of this study is to investigate empirically the relationship between the efficiency of value creation and financial performance by capturing the perceptions of intellectual capital in the banking industry and identifying the value of the variables within the bank's organization using pulic method, namely value added intellectual coefficient (VAIC) and dependent variable is Return on Assets (ROA).

Research on intellectual capital (IC) continues to grow in connection with other variables that are associated with the level of cost efficiency that can be managed by the company. One of them is [4] using the General Structure Component Analysis (GSCA) explain the linkage between corporate governance, intellectual capital, with financial performance and firm value. The corporate governance indicators used are the proportions of independent auditors and commissioners, intellectual capital using VACA, VAHU, and STVA. Financial performance using ROA and ROE, one indicator of corporate value using closing price. It found that corporate governance significantly negative to financial performance and corporate value, intellectual capital has significant effect to financial performance and firm value, and financial performance have an effect on company value.

Based on previous studies, this research tries to add variable Capital Adequacy Ratio that enable there is influence to bank performance in Indonesia, because from some research on intellectual capital that has been done, generally only connect intellectual capital with company performance both financial performance and performance market or company value. The purpose of this research is to analyze the effect of Value Added Human Capital (VAHU), Structural Capital Value Added (STVA), and Value Added Intellectual Capital (VAIC) and Capital Adequacy Ratio (CAR) to Return On Asset (ROA).

\section{LITERATURE REVIEW}

According to Bozzolan et al. states intellectual capital is whole information useful for investors and analysis [5]. On the other hand, Brennan defines intellectual capital as knowledge transferred to produce high asset value to increase company value. Furthermore, Brennan states that the value of intellectual 
$\mathrm{ROA}_{\text {it }}=\beta_{0}+\beta_{1} * \mathrm{VAHU}_{\mathrm{it}}+\beta_{2} * \mathrm{STVA}_{\mathrm{it}}+\beta_{3} * \mathrm{VAIC}_{\mathrm{it}}+$

$\beta_{4} * \mathrm{CAR}_{\text {it }}+\mathrm{e}_{\mathrm{it}}$

value of a company [6]. Abeysekera and Guthrie define intellectual capital as capital that is not accounted for in traditional accounting systems, it can be stated that the market value of the firm is influenced by several factors, some of which can be controlled and others are not controlled by the company [7].

Stewart, defines intellectual capital in his article "the sum of everything in your company knows that it is intellectual material-knowledge, information, intellectual property, experience-that can be put to use to create wealth" intellectual is the sum of everyone in the company that provides a competitive advantage in the marketplace-intellectual knowledge, information, intellectual wealth, experience-that can be used to create wealth.

Sawarjuwono and Kadir states that IC measurement methods are grouped into two groups [8]: nonmonetary measurements and monetary measurements. One method of measuring intellectual capital with nonmonetary valuation is Balanced Scorecard by Kaplan and Norton, while the method of measuring intellectual capital with monetary valuation one of them is a pulic model known as VAIC.

VAIC is used as a suitable indicator for measuring IC in empirical research. Some of the main reasons supporting the use of VAIC are, firstly, the VAIC provides a standard and consistent measure, the standard financial figures generally available from corporate financial statements [9], making it possible to more effectively perform international comparative analyzes using sizes until large in various industry sectors. Both of the data used in VAIC calculations are based on audited information so that calculations can be considered objective and verifiable $[10,11]$.

VAIC is an analytical procedure designed to enable management, shareholders and other relevant stakeholders to effectively monitor and evaluate value added efficiency or Value Added (VA) with the total value of enterprise resources and each of the major resource components. Value added VA is the difference of income (OUT) and load (IN).

The ownership structure is a share of ownership by managerial, public or institutional. Shareholders monitor the board of directors and managers in any decision-making and responsibility in accordance with company policy set forth in the General Meeting of Shareholders (GMS).

\section{MEthodS}

The population in this study is a banking company listed on the Indonesian stock exchange (ISX). The banking sector generally offers the ideal field of intellectual capital research. This study uses financial report data for the last 5 years (20132017) which is the latest data company that can provide an updated picture of the company's financial performance. The sampling technique using purposive sampling is the selection of non-random samples. Based on the consideration obtained the number of samples for the year 2013 - 2017 which will be used in the research are as many as 20 samples listed on the ISX. The following is a multiple regression model in this study:
Where $i$ refers to the bank, $t$ refers to the years

ROA $=$ Return On Assets

VAHU = Value Human Capital

STVA= Structural Capital Value Added

VAIC $=$ Value Added Intellectual Capital

$\mathrm{CAR}=$ Capital Adequacy Ratio

$\varepsilon=$ Standard Error

\section{RESUlTS AND DISCUSSION}

The result of the influence of independent variable to the dependent variable can be seen at the value of $\mathrm{F}$ as follows:

TABLE I. RESULT OF THE INFLUENCE VARIABLE

\begin{tabular}{|c|c|c|c|c|c|c|}
\hline & Model & $\begin{array}{c}\text { Sum of } \\
\text { Squares }\end{array}$ & df & $\begin{array}{c}\text { Mean } \\
\text { Square }\end{array}$ & $\mathbf{F}$ & Sig. \\
\hline \multirow[t]{3}{*}{1} & Regression & 17.392 & 4 & 4.348 & 12.903 & $.000^{\mathrm{b}}$ \\
\hline & $\mathrm{R}$ residual & 32.012 & 95 & 337 & & \\
\hline & Total & 49.404 & 99 & & & \\
\hline
\end{tabular}

This is to see how significant each independent variable affects the dependent variable. The hypotheses are formulated as follows:

TABLE II. RESUlt OF SIGNIFICANT VARIABLE

\begin{tabular}{|c|c|c|c|c|c|c|}
\hline & \multirow[b]{2}{*}{ Model } & \multicolumn{2}{|c|}{$\begin{array}{l}\text { Unstandardized } \\
\text { Coefficients }\end{array}$} & \multirow{2}{*}{\begin{tabular}{|c|}
$\begin{array}{c}\text { Standardize } \\
\text { d } \\
\text { Coefficients }\end{array}$ \\
Beta \\
\end{tabular}} & \multirow[b]{2}{*}{$\mathbf{t}$} & \multirow[b]{2}{*}{ Sig. } \\
\hline & & $B$ & Std. Error & & & \\
\hline 1 & \begin{tabular}{|l} 
(Con \\
(Constant)
\end{tabular} & .114 & .351 & & .324 & .747 \\
\hline & VAHU_X1 & 751 & .304 & .372 & 2.467 & .015 \\
\hline & STVA_X2 & .797 & .464 & .247 & 1.718 & .089 \\
\hline & VAIC_X3 & -.446 & .179 & -.240 & -2.489 & .015 \\
\hline & CAR_X4 & .016 & .008 & .166 & 1.996 & .049 \\
\hline
\end{tabular}

TABLE III. RESUlt OF KOEFISIEN DETERMINASI R2

\begin{tabular}{|c|c|c|l|l|l|}
\hline Model & R & R Square & $\begin{array}{c}\text { Adjusted R } \\
\text { Square }\end{array}$ & $\begin{array}{l}\text { Std. Error of } \\
\text { the Estimate }\end{array}$ & $\begin{array}{c}\text { Durbin- } \\
\text { Watson }\end{array}$ \\
\hline 1 & $.593^{\mathrm{a}}$ & .352 & .325 & .58049 & 1.835 \\
\hline \multicolumn{5}{r}{ a. Predictors: (Constant), CAR_X4, VAIC_X3, STVA_X2, VAHU_X1 } \\
\hline \multicolumn{5}{|c|}{}
\end{tabular}

b. Dependent Variable: ROA

From the table above shows that the variables VAHU, STVA, VAIC and CAR affect the ROA. Based on the above table shows $\mathrm{R}$ square is 0.352 or $35.2 \%$ can explain variable of ROA while $57.5 \%$ explained by other variable. 
The results showed that the VAHU variable had a positive effect on ROA, indicating that a high VAHU could give an idea that if the company's employee load rise, it was expected that employee performance could rise, it would increase the company's profit. The results of this study are consistent with previous research conducted by Hamidah et al. which states that VAHU has a positive and significant effect on bank performance [12].

The results showed that the STVA variable affected company performance at commercial banks listed on the Indonesia Stock Exchange showed that companies that were able to manage their capital well were the benchmarks for business success only in increasing physical capital and not yet in optimizing company structure, systems, good procedures, regulations and data base in which the company hopes to be able to minimize financial losses, fraud, risk of bank bad loans.

The results showed that the VAIC variable had a negative effect on ROA, indicating that the bank allocated more funds to finance intellectual capital in the form of human resources. This condition will increase the competence and capability of human resources so that it can increase company profits. The results of this study are in accordance with previous research conducted by Riyanti and Rahardjo which states that VAIC has a significant effect on company performance [13].

The results showed that the CAR variable had a positive effect on ROA showing the higher ability of bank capital to maintain the likelihood of loan risk so that bank performance also improved. CAR is an indicator of a bank's ability to cover its assets reductions as a result of bank losses caused by risky assets. The higher the CAR, the better the bank's ability to bear the risk of any risky credit or productive assets. The results of this study are consistent with previous research conducted by Pasaribu and Sari [14].

\section{CONCLUSION}

The results of the discussion that has been described in the previous chapters supported by the existing data, the authors can be concluded as follows: Value Added Human Capital (VAHU), Strutural Capital Value Added (STVA), Value Added Intellectual Capital (VAIC) and Capital Adequacy Ratio (CAR) have influence to Return On Asset (ROA). Based on the research there are several suggestions for the improvement of similar research in the future, and for further research is expected to examine the variables other than the variables used in this study that may affect the banks performance.

\section{REFERENCES}

[1] L. Edvinsson and M.S. Malone. Intellectual Capital: Realizing Your Company's True Value by Finding Its Hidden Brainpower. New York: HarperCollins, 1997.

[2] F. N. Al-Shubiri, "Capital Structure and Market Power: Evidence from Jordanian Banks,” Managing Global Transition, vol. 9, pp. 289310, 2011.

[3] S. Saengchan, "The Role of Intellectual Capital in Creating Value in the Banking Industry," Intercom, 2008.

[4] Z. Arifin, Penelitian Pendidikan: Metode dan Paradigma Baru. Bandung: PT Remaja Rosdakarya, 2014.

[5] S. Bozzolan, F. Favotto, and F. Ricceri, "Italian annual intellectual capital disclosure: An empirical analysis," Journal of Intellectual Capital, vol. 4, no. 4, pp. 543-558, 2003

[6] N. Brennan, "Reporting Intellectual Capital in Annual Reports: Evidence from Ireland," Accounting, Auditing and Accountability Journal, vol. 14, no. 4, pp. 423-436, 2001.

[7] I. Abeysekera and J. Guthrie, "An Empirical Investigation of Annual Reporting Trends of Intellectual Capital in Sri Lanka," Critical Perspective on Accounting, vol. 16, Iss. 3, pp. 151-163, 2005

[8] T. Sawarjuwono and A.P. Kadir, "Intellectual capital: perlakuan, pengukuran dan pelaporan (Sebuah library research)," Jurnal Akuntansi dan Keuangan, vol. 5, no. 1, 2003.

[9] Pulic, M. Bornemann, and K.H. Leitner, "Measuring and reporting intellectual capital: the case of a research technology organisation," Singapore Management Review, vol. 24, no. (3), pp. 719.,1999.

[10] Pulic, "VAIC - An Accounting Tool for IC Management," International Journal of Technology Management, vol. 20, no. (5), 2000.

[11] Pulic, "Measuring the performance of intellectual potential in knowledge economy," Paper presented at the 2nd World Congress on Measuring and Managing Intellectual Capital, McMaster University, Hamilton, 1998.

[12] Hamidah, P. Dian, and M. Umi, "Pengaruh Intelenctual Capital Terhadap Kinerja Keuangan pada Bank Go Public yang Terdaftar di bursa Efek Indonesia (BEI) Tahun 2010-2012,” Jurnal Riset Manajemen Sains Indonesia (JRMSI), 2015.

[13] N. Riyanti and S. Rahardjo, "Analisis pengaruh Intellectual Capital dan Corporate Governance Terhadap Financial Performance," Jurnal Akutansi fakultas Ekonomika dan Bisnis Universitas Diponegoro, 2012.

[14] H. Pasaribu and R.L. Sari, "Analisis Tingkat kecukupan Modal dan Loan to Deposit Ratio Terhadap Profitabilitas," Jurnal telaah dan Riset Akuntansi, 2011. 